\title{
Review of the Implementation of South Sudan's National Gender Policy in Jubek State, South Sudan
}

\author{
Mburu Joseph Njoroge, Dr. Edna Moi \\ Kenyatta University, Kenya
}

\begin{abstract}
Most studies have shown that gender mainstreaming in South Sudan has not been well undertaken this is due to lack of working policy or lack of policy implementation. While expansive body of literature has explored the implications of gender disparities in South Sudan, none has been published on the impact National Gender Policy full implementation. This study aims at assessing the implementation of South Sudan National Gender Policy in Jubek State, South Sudan. The study was guided by three objectives namely; to identify the gender gaps in the National gender Policy as a step towards achieving gender equality in Jubek state in gender mainstreaming in Jubek State; and to determine stakeholders' achievement in a national gender policy in Jubek State. The study employed a stand point theory. A population of 350 government officials and members of the public in the Jubek State targeted in the study with a randomly selected sample of 105 respondents. Members of the public responded to questionnaire while Government Officials to respond to both interview guide questionnaire. The aim of the study was to assess this strategies that help in the implementation of Gender policy in all government Ministries. The study employed descriptive and inferential analysis with the aid of Statistical Package for the Social Sciences and data presented by Charts and tables. The study further revealed that despite the existence of South Sudan National Gender Policy its implementation is still a not clear since the general public is not even aware of its existence and there is no awareness to the public on the importance of the South Sudan National Gender Policy. The study further concluded that there is no emphasis national gender policy in gender mainstreaming. Gender responsive training and retraining programs have not been established. There are also no adequate resources allocated for gender mainstreaming. The government doesn't increase financial allocation for interventions to increase retention rates for girls and boys in schools. Thus the national gender policy in gender mainstreaming has not produced any success. The study findings further revealed that stakeholders in national gender policy have not achieved a lot. The study recommends that, there is need for the government state ministries to establish more strict measures to ensure there is gender equity in employment in both private and public service. There is also need for the government stakeholders to create awareness to the public on the importance and implementation of Sudan National Gender Policy (SSNGP). The government should allocate adequate resources for gender mainstreaming. The government also needs to increase financial allocation for interventions to increase retention rates for girls and boys in schools. Thus the national gender policy in gender mainstreaming has not produced any success
\end{abstract}

\section{INTRODUCTION.}

\subsection{Background of the study}

Gender mainstreaming is continuously being considered as sections of opinion, education, health, political depiction, land ownership, occupation, remuneration, and family setup. Walby (2005) stated that through empowerment, people have begun to understand that collective activity is expected from all in order for sexual orientation homogeneity to work. Countries are decent to eliminate the social factors that limit sexual orientation mainstreaming, just as they are preparing human and financial assets for successful sexual orientation mainstreaming. The concern of a disparity that is present amongst women and men in certain areas including decision making positions is being faced with universal uncertainty.

Over the previous years, gender mainstreaming in Africa was going via approach of mobilization by involvement of certain state and non-state actors. In this context, Women have been underestimated at all dynamic levels, especially in the areas of organization and parliament. For example, recalling the dynamic women's situation sent to Congress via the Zambian Research and Development Association (ZARD) in 2011, we found that gender-specific imbalances were identified as a result of the downturn. Only seven women represented women in the political and prestigious administration of the 35 permanent secretaries. In addition, a review found that there was no Deputy Vice-Minister (ZARD, 2011),

In local setting, South Sudan's three common conflicts (19551972, 1983-2005, and 2016) left the country in a helpless situation. The population has been uprooted and the scaffolding has been shattered. This created real need and underdevelopment in all areas, and therefore women and children endured the worst of these amazing effects of war. Due to the deaths of a huge number of men in conflict or their long no-show, women undertook jobs that were usually reserved for men. The realization of unity with the approval of the Comprehensive Peace Agreement (CPA), in particular, keeps the majority of rural women away from authority and violence by maintaining inconsistent relationships of power with socially determined work.

Approval of basic work done by women returns to the Chukdam Convention, which defines the Department of State for women and children in the South Sudan Liberation Movement (SPLM). After its inauguration, it was reconfirmed through the Joint Evaluation Mission (JAM) in 2004, 
recognizing the need to promote uniformity of sexual orientation, and the proposal was made in the second half of the CPA, the 25th Confirmation Action Conditions (South). Proposed with Sudan's Provisional Constitution). Since 2011).

The Interim Constitution fortified the acknowledgment of equivalent privileges for ladies and men with novel arrangements for ladies that were remembered for the Transitional Constitution of 2011. Besides, the Ministry of Gender, Child and Social Welfare that was before known as Ministry of Gender, Social Welfare and Religious Affairs was set up in the year 2006 with a command to advance the fulfillment of sex equity just as organizing the public sexual orientation hardware in a joint effort with Ministries of Gender and Social Development at State level (National Gender Policy, 2013). This gender policy looks at consolidating the achievements by presenting guidelines as well as strategies that look for an additionally structured process to attain gender equality as well as the empowerment of women as a key to sustainable growth (Bubenzer \& Lacey, 2013).

The policy confirms the government commitment to dealing with gender equality as well as women's empowerment concerns at all levels with an aim of ensuing elimination of all kinds of discrimination. It presents an overall climate for mainstreaming sexual orientation equity in all public advancement techniques and a system where public just as area arrangements and projects will be based to investigate present imbalances consequently resolve verifiable disparities. The National Gender Policy Strategic Plan for implementation of SSNGP provides a guiding as well as direct planning and implementation roadmap for gender equality interventioans. It defines new criteria for prioritizing, mobilizing and allocating resources. This ensures equal access to national goods and services (National Gender Policy, 2013).

National Gender Policy presents clear political guidelines and strategic directions to mainstream gender in national growth and emulate some of the other best practices to achieve gender equality. As a result, there are concerns (Bubenzer \& Lacey, 2013). This presents benchmarks for looking into the acknowledged priority requirements for women, girls, men, boys and susceptible groups in addition to approaches for answering to their issues. It is pointed toward affecting all public, state, neighborhood government, private area alongside the common society cycles and constructions to speed up sure change and capitalize on the advantages of advancement for ladies, men and youngsters.

\subsection{Statement of the Problem}

Despite the numerous achievements by the republic of South Sudan in developing a gender policy, there still remain several challenges that need to be addressed. Issues such as insecurity and weak judicial system are deemed to be closely linked to empowerment of women. (South Sudan's National Gender policy, 2013). In South Sudan, humans overwhelm all areas of life, possess, control and power the most useful resources. The limited traditional school education of many South Sudanese women reduces the likelihood of being completely interested in friendly economic and political debates, thus making it difficult to obtain financial means. The negative effects of this underestimation mean that some of the country's population is affected and has a significant negative impact on progress. Edward (2014) praised the $25 \%$ government policy on social minorities in the provisional constitution and introduced increased political interest in the parliament and rational representatives of women, but states like Juvek. He said there was still an imbalance in his community.

More or less the need / limited proper guidance of many South Sudanese women diminishes their ability to fully engage in friendly financial and political debates and empowers them financially. Understand formal training that makes it difficult and gives the impression that sisters have an advantage (South Sudan National Women's Methodology Report, 2016). The impact of these deviations is evident in administrative, judicial and neighboring government meetings.

For this reason, the Government of South Sudan has created a Government Assistance NGP through the Ministry of Gender, Children and Social Affairs to provide clear rules for dealing with such gender differences. To achieve this, the NGP had to be fully implemented but very few scholars have directed their attention to its implementation neither the impact it has had on the general public. Although gender is an expansive issue, this research seeks to focus on three aspects of implementation namely; gender gaps in the National Gender Policy, effectiveness of the National Gender Policy in gender mainstreaming, and stakeholders' achievement in the National Gender Policy.

\subsection{Research Objectives}

1. To identify the gender gaps in the National gender Policy as a step towards achieving gender equality in Jubek state

2. To determine the success of the national gender policy in gender mainstreaming in Jubek State

3. To determine stakeholders' achievement in national gender policy in Jubek State

\subsection{Research Questions}

The study project is determined to answer the study questions below with relation to the project aims;

1. Are there gender gaps in the National Gender Policy as a step towards achieving gender equality in Jubek state?

2. Is the National Gender Policy effective in gender mainstreaming in Jubek State? and

3. What has stakeholders in Jubek State's achieved in the National Gender Policy?

\subsection{Justification and Significance of the Study}

First, Jubek State hosts the Capital city of South Sudan, a country that has been revenged by internal conflicts leading to increased gender disparities in almost all institutions. The 
research will also help in strengthening the debate concerning the importance and benefits of women empowerment so as to achieve equity and equality in gender in all sectors of the economy in order to spur justifiable growth in the Country. The study will also assist the stakeholders to develop and design programs and initiatives that will encourage participation of younger women with a view to gaining experience and build their leadership skills. It will also serve to inform specific steps and intervention that should be undertaken to achieve full implementation of the policy and hence gender equality in Jubek State. Lastly, South Sudan being a young country, more research is needed in future, as scholars continuously examine the impact of gender policy from different perspectives. In that respect, this study will serve as a baseline guide to similar studies in future by presenting the much needed literature

\section{CHAPTER TWO LITERATURE REVIEW}

\subsection{Introduction}

This section debates the empirical review, literature review and the study conceptual framework to inform the strategies that help in the implementation of Gender policy in all government Ministries as well as amongst all the populace.

\subsubsection{Gender gaps}

Gender gaps are as result of social as opposed to biological differences. Gender gaps manifest themselves in education, health, economic empowerment, political representation, job opportunities, and ownership of land and in environment management. With a focus on rural women, gender gaps exists in every sector mentioned above and plays a key role in impeding women's progress in economic empowerment. In the world's population, over half is made up of women while only 20.9 per cent of legislators are female worldwide (InterParliamentary Union 2013). Positive measures including quotas have over time been considered as efficient approaches for redressing gender gaps in power relations, and have been embraced by more than 130 nations all through the world.

South Sudan was admitted to by the General Assembly on 3 July 2011 as being the $193^{\text {rd }}$ member state of the United Nations. Following this, the country was also enrolled as a member of IGAD and AU. Additionally, the nation endorsed the Geneva Convention that bound it to maintain international humanitarian law. Despite taking these steps, the country has not yet sanctioned CEDAW and additional vital conventions that back equality in gender, the key beliefs of the research tools are mirrored in state legal tools (Abusharaf, 2009). Pledge to equality gender and the liberation of women are preserved in requirements of the Transitional Constitution and the Bill of Rights that present assurances for equality as well as fairness amongst women and men as provisional positive measure to compensate past inequalities. Some of the laws that have been ratified comprising the Child Act of 2008 additionally indicated that there is desire to address the past imbalances. Governmental will to improve equality in gender was shown through the formulation of the MGCSW in year 2006.

The NGP in South Sudan was developed in 2013 when also its implementation strategy came to effect. The NGP came due to thorough consultation with varying stakeholders in private, administration and state levels, development partners, national as well as international businesses. Ali (2011) noted that the policy serves as a structure and presents frameworks for streamlining values of equality gender in addition to the empowerment of women in the national development approaches with the eventual goal being making equality gender an essential part of all regulations, strategies of all administration associations, remote sector as well as civic society. Taking into consideration the given mandate, the precise goals of the national gender policy include; creation of a policy environment that is enabling with regards to the translation of the government dedication to gender equality (Mannan et al., 2012); establishment of policies, structures, mechanisms and programs to transform and empower women and the gender relations in every aspects of work at every level of the government and in the general society (MacLachlan et al., 2012), and to ascertain that the gender considerations are successfully integrated into every aspects of government program and policy activities (Barriteau, 2000). The national gender policy include the establishment of institutional frameworks for the improvement of women status and the accomplishment of gender equality, advocating for the promotion of novel approaches, behaviors and values, as well as a culture of respect for every human beings in proportion to the novel policy (Holmarsdottir, Ekne \& Augestad, 2011). Lastly, in addition to guiding the development of South Sudan's National Gender Action Plan,

\subsubsection{Effectiveness of the National Gender Policy in gender mainstreaming}

The national gender policy materialized as a result of the accommodating temperament of gender favoritism globally. Both the control over and accessibility to resources within the political and economic spheres is broadening (Plantenga, 2004). This has, therefore, made the promotion of gender equality vital if not essential, as it is a key aspect that contributes to development. A nation's progress is mainly established through individuals given that both men and women alike are always striving to find the ways of escaping poverty and improving their living standards. Based on the above observation, the realization of gender equality cannot only be perceived as an end but also as an essential requirement for the accomplishment of sustainable development (Osman, 2002). This is one of the key reasons why women empowerment and gender equality remains to be one of the key subjects of discussion in various global conventions, treaties and declarations. The year 1948 witnessed the global expression of the secular state's guiding principles \& human rights culture at the United Nations Universal Declaration of Human Rights (UDHR) and in which nearly every nation was in agreement with the basic human rights common standards, whereas they additionally 
prohibited discriminations based on aspects. A policy must have both a framework and a guiding principle that guides the effortless riming of the plans in an attempt to realize the motivation behind its institution (Carey, 2001). Tackling the issue of women empowerment programs unaided cannot resolve the difficulties of imbalanced gender relations in South Sudan, and as such, the policy's key thrust regards the elemental fact driving the policy; it is impossible to consider women devoid of the participation of men given the recognition that the a nation is incapable of achieving any degree of sustainable growth and development minus eliminating the gender gaps in the productive agents of the economies (Fordham, 2003).

According to Scott et al. (2013) African nations including South Sudan have remained pervasive with regards to the infringement on human rights in areas that include Women are nauseatingly devalued and violated in South Sudan and other African nations (Scott et al., 2013). This is referred to as the country's Gender Development Index (GDI), and is mainly manifested through the low partaking of women in paid labor, leadership, politics and decision making, as well as an equally higher rate of sexual and physical harassment and physical attack, human trafficking, early and forced marriages, marital rape and diverse stages of detrimental traditional practices exercised against the girl child and women (Carey, 2001).

\subsubsection{Stakeholders achievement}

Gender stakeholders are directly linked to participatory. Recently participatory governance has become a new way of developing public policies. Participatory governance acknowledges the fact that both representative and participatory aspects of democracy are vital in public policy making process. This aspect of governance allows citizens to own the process of public policy development, its implementation monitoring and evaluation. Participatory governance therefore stands as one of the major prerequisite for the advancement of gender equality as highly acknowledged at the international arena. Dagne (2012) notes that the gender policy seeks to reinforce the women's voice in the civil society, parliament and the legislations that have already made perceptible effects through the challenge of gender arid policies and blind laws, as well as the advancement of work that is already being performed by the ministry at the local and national government levels and the development agencies devoted to the issues of gender equality and equity, and women empowerment (De Waal \& Mohammed, 2014).

The Beijing Platform for Action 1995 encourages and promote active participation of civil societies, public and private actors to work as a team to achieve equality in gender between men and women to be realized. The significance of stakeholders' participation in the tracking down of success in gender equality was strengthened by European Institute for Gender Equality's 2014 report on the efficiency of the institutional contrivances for the development of gender equality. The report underscores the need to involve stakeholders such as civil society as a complaint for formation and execution of gender equality and mainstreaming policies. The United Nations Economic Commission for Europe also recommends the involvement of participants in the attainment of gender equality. It is vital that South Sudan embraces the gender policy to emphasize the gender standpoint with regards to every aspect of legislation development, planning policies and the various transformation activities. As such, Hudson (2009) notes that the objective of the national gender policy is mainly to concentrate on tackling the systematic inequalities existing between men and women in the society devoid of disregarding the elemental divergences between them. The national gender policy, therefore, seeks to articulate the challenges and problems, imperatives, visions, objectives, outputs and commitments, as well as strategies for attaining gender parity, in addition to the framework of monitoring and execution (Govender \& Vyas-Doorgapersad, 2013). As such, Hudson (2009) observes that as a holistic policy, the national gender policy is meant to make certain the complete national transformation and reorientation with regards to reduction of poverty, and equitable and sustainable growth, one of the key reasons for its articulation in the nation's existent policy framework.

Therefore, it will work out a comprehensible vision of the country's goals with regards to gender equality, derived from the country and international vision on gender equality as indicated in the ongoing debates in the global arena (Carey, 2001). The objective of gender equality is transformation, and similar to every change process, it is prone to run into impediments arising from individual, organizational and group interests (Edward, 2014).

Despite there being some considerable progress in the implementation of the Beijing declaration and platform for action in, there is restricted institutional framework to reinforce the good achievements, capacity of these institutions being weak and combined with human resources capacity is one huge challenge limiting the advancement of gender equality and women's empowerment (Edward, 2011). In the country, there are existent unbalanced power relations and prospects among women and men at all levels of administration (Edward, 2011). Even with the $25 \%$ in the affirmative action that is commendable and has brought improved participation of women in the legislative assembly, disparities and differences are still visible and wide enough in legislative assemblies, executive level in public administration. The capability of women to efficiently contribute and engage with their male counterpart in leadership as well as decision making is still limited.

\subsection{Critical Review of Related Literature}

According to (Plantenga, 2004), gender refers to the word employed in the description of personality and social disparities between men and women; thus, it is used in referral to that which has been described by the society as feminine and masculine (Ali, 2011). In South Sudan, efforts have been 
made to tackle the issue of the rights and responsibilities of the female gender, and the most recent discussions on the subject with the objective of improving the social, political and economic rights of the South Sudanese women in general; however, the framework and the guiding principles used in doing so tends to be very weak and this has been attributed to the observation that gender-based matters are beyond the women empowerment approach, as well as the narrow concepts of women in development (WID) to an increasingly and the comprehensive gender and development (GAD) approach.

In South Sudan, the vital documents redirecting aspects such as gender-based equality, enhanced standards of living, and development of a fair society that lacks gender-based discrimination, harnessing the free fall potential of every social group, notwithstanding of conditions and gender have materialized in recent times and give both women and men equal voices with regards to policy execution and decision making. Therefore, this study has made attempts at clarifying the gender concept through provision of a review of the earlier attempts, the motivation behind the materialization of NGP in addition to elucidating its objectives and goals, the framework of its operations and the guiding principles.

In order to understand the execution of gender policy in South Sudan, the understanding of the Concept of Gender is imperative. Thus, according to (Mannan et al., 2012), the distinguishing of gender is usually done using the word "sex", as a consequence of the observation that on most occasions, the observation that on most occasions, the gender concepts are employed interchangeably. As noted earlier, gender is utilized in describing the personality and social dissimilarities existing between women and men, and describes that which has been described by the society as feminine and masculine whereas sex, on the contrary, is used in reference to the term that is employed in classifying species into male or female, even as the female unaided might produce offspring and also breast feed whilst the male genital structure and hormonal diverge from the females. Comprehending the disparities that exist between sex and gender and between women and men is imperative as it enables the determination through nature, as well as that that has been described socially as appropriate for females and males (Ali, 2011).

Sex is considered to be mainly about the biological variations that are understandable and might be observed physically along with the manner in which men and women live their lives. This may also be described in terms of the biological variations between the two, and in a similar fashion to the existence of social disparities between the females and males (Osman, 2002). Dissimilar to gender, sex refers to a widely employed term used in describing and differentiating the females from the males and conversely as a result of its stable facets and relativity; gender tends to be a concept that is increasingly more variable as societies define it differently, and the definition within a society might also differ with time (MacLachlan et al., 2012). This is mainly as result of its increased emphasis on personality and social differences existing amongst the females and males and also between them. As such, gender inequality regards the different treatment of either of the genders economically, educationally and politically, and this hampers the development and growth given that the vital biological variations existing tends to disconnect the society unequally with regards to the female and male labor, expectation and power roles (Holmarsdottir, Ekne \& Augestad, 2011).

In their studies, (Bauer 2012; Krook 2010; Lovenduski 2005) noted that the unpredictable results of women's representation are the outcome of institutional environment, political elites' prejudice, and the interaction of factors of supply and demand. The proof attracts attention to the complexity of quotas and implores comprehensive exploration of adoption as well as implementation approaches especially in the context of postconflict plus transition to democracy nations. In numerous studies concerning quotas, the outcomes indicated that the number of nations that have adopted quotas have noted gaps among quota provisions and outcomes and quota rules without details analysis of implementation (Bauer 2012; Ballington 2004; Krook 2009).

\subsection{Theoretical Framework}

\subsubsection{Stand point theory}

This study was based on the Standpoint Theory by Dorothy Smith (1977), which has effectively utilized the standpoint notion to lay emphasis that whatever an individual knows is always affected by his or her stand point in the society. The objective of the feminist sociology by Smith is to overtly reformulate the sociological theory through folly accounting gender standpoint and its impact on his reality experience. This theory assumed as a female in a world under the dominance of the males, and, in particular, as a mother, wife and as a sociology graduate learner, which brought about her formulation of her conception of standpoint. Therefore it informs the objectives of this study on gender mainstreaming. In a nutshell, Smith give emphasis to not only the observation that the male stand point is constantly advantaged even as the female standpoint is devalued, but also to the observation that the male standpoint tends to not only pervade but also dominates the other notable world views. As Smith observed in her 1977 work "the Feminism and Marxist", there is a link between the Marxian and her feminism. She clarifies the way the "objective social, political and economic relations tend to determine and shape the oppression of women's oppression.

\subsection{Conceptual Framework}

The conceptual framework can be termed as a written product or visual which shows the connection between variables used in the study. The significance of this is to aid the study researcher have clear objectives of the research, advance accuracy of the research questions, aid in selecting recommended approaches and classify possible validity coercions to the research. 


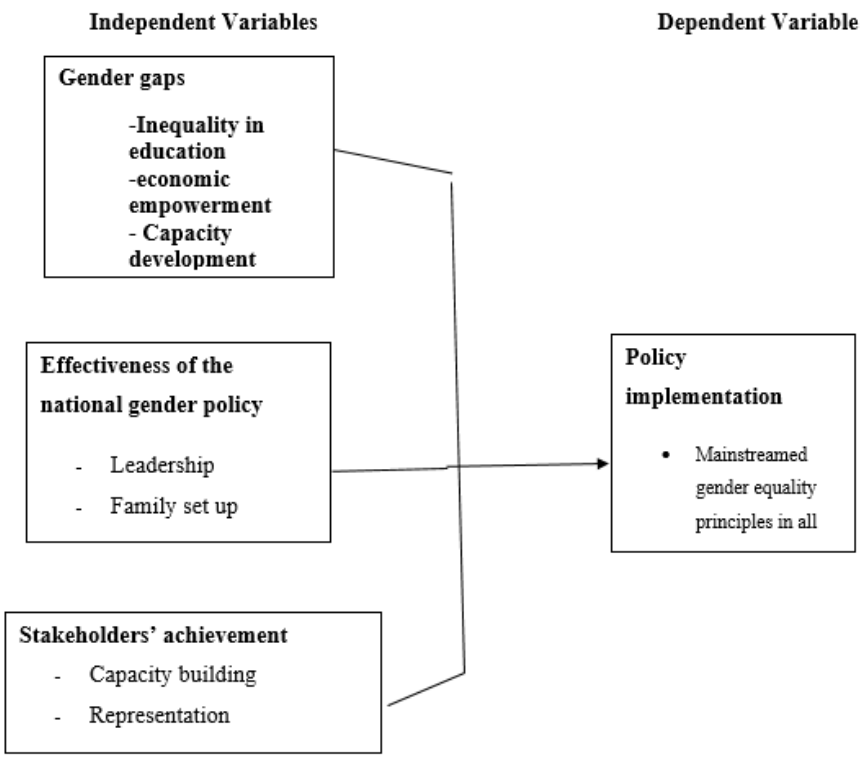

Figure 1.1 Conceptual Framework

Source: Researcher 2021

According to the classic study, Mackay (2008) noted that representation happens in the scenario political representatives perform for their constituents in a responsive manner and in the context of periodic authorization and accountability.

On the other hand, arguments by feminist scholars indicate that the descriptive representation of women is vital. Their reason is that the rejection of women from political life is of itself a concern for democracy. The equivalent presence of women in political institutes is the related solution and quotas are the mechanisms needed to secure equality of representation. Feminist researchers back quotas on a variety of grounds involving those of justice, legitimacy, fairness, interests and difference. Symbolically, the presence of women in leadership positions improves the legitimacy of a democratic nation.

\section{RESEARCH METHODOLOGY / DESIGN}

\subsection{Introduction}

This segment of the review portrays how the exploration was led. It comprised of an exploration plan, the members, information assortment, wellsprings of information and tests. Also, an evaluation was done on the blunders that may emerge while leading the exploration and the dependability of the instruments that was utilized. A moral thought was additionally being examined.

Table 1: Categories of analysis

\begin{tabular}{|c|c|c|}
\hline Type of variable & Indicators & $\begin{array}{l}\text { Measurement } \\
\text { scale }\end{array}$ \\
\hline Gender gaps & $\begin{array}{l}\text { - Inequality in } \\
\text { education } \\
\text { - economic } \\
\text { empowerment } \\
\text { - Capacity } \\
\text { development }\end{array}$ & Descriptive \\
\hline
\end{tabular}

\begin{tabular}{|l|l|l|}
\hline $\begin{array}{l}\text { Effectiveness of the } \\
\text { national gender policy }\end{array}$ & $\begin{array}{l}\text {-Leadership } \\
\text { - Family set up }\end{array}$ & Ordinal \\
\hline $\begin{array}{l}\text { Stakeholders' } \\
\text { achievement }\end{array}$ & $\begin{array}{l}\text {-Capacity building } \\
\text { - Representation } \\
\text { - Equality }\end{array}$ & Ordinal \\
\hline
\end{tabular}

\subsection{Research Design}

This review utilized the illustrative sort of exploration plan. Spellbinding exploration is applied in assortment of data that respects the current peculiarities status and hence help in depicting "what exists" concerning factors or even conditions that are available in a review circumstance (Mugenda, and Mugenda, 2003.

\subsection{Study location}

The gender assessment was done in every one of the fourteen districts of Jubek State which has the National capital, Juba which is likewise the biggest city in South Sudan with a populace of 492,970 (2014 registration). The duplicates of NGP have been scattered to every one of the nine State services spread across the whole State in particular; Gender, Child and Social Welfare, Education, Finance, Interior, Justice, Agriculture, Health, Public Service and South Sudan Human Rights Commission (SSHRC) that offers administrations to the general population and whose authorities are focused on in the review. The appraisal districts incorporate; Lodu, Mogalla, Luri, Gondokora, Rajaf, Lobonok, Wondurumba, Ganji, Bungu, Dollo, Lyria, Rokon and Oponi (Presidential declaration of 2015). Government authorities, in carrying out the NGP, are relied upon to give appropriate orders and directions commanded to standard both general society and private projects in the South Sudan.

\subsection{Target Population}

Populace in this review is named as the review populace gathering, articles and occasions that have a typical trademark that could be noticed (Mugenda and Mugenda, 2012). The review populace of this review was comprised of government authorities of Jubek State and beneficiaries of different taxpayer driven organizations. Along these lines residents were focused on to give their viewpoints on the help quality they get from those workplaces. Nonetheless, the review looked to include a chosen handful as shown in the table 3.2

\subsection{Sampling Technique \& Sample Size}

From the target population of 350 government officials and general public, the researcher selected select 65 members of the public and 45 government officials of Jubek State in the State Ministries of; Gender, Education, Health, Justice, Interior, Finance, Agriculture, Public Service and South Sudan Human Rights Commission. This added add up to a sample population of 105 respondents representing a 30\% of the total number of target population. 
Table 3.2 Sample Size

\begin{tabular}{|c|c|c|c|}
\hline $\begin{array}{c}\text { Respondents } \\
\text { in the State } \\
\text { Ministries }\end{array}$ & $\begin{array}{c}\text { Target } \\
\text { Population }\end{array}$ & $\begin{array}{c}\text { Government } \\
\text { Officials' } \\
\text { Sample } \\
\text { Population }\end{array}$ & $\begin{array}{c}\text { General public's } \\
\text { Sample population }\end{array}$ \\
\hline $\begin{array}{c}\text { Gender, Child } \\
\text { and Social } \\
\text { Welfare }\end{array}$ & 44 & 5 & 11 \\
\hline Education & 40 & 5 & 7 \\
\hline Finance & 34 & 5 & 7 \\
\hline Interior & 41 & 5 & 6 \\
\hline Justice & 36 & 5 & 5 \\
\hline Agriculture & 40 & 5 & 7 \\
\hline Health & 42 & 5 & 6 \\
\hline Public Service & 38 & 5 & 5 \\
\hline $\begin{array}{c}\text { South Sudan } \\
\text { Human Rights } \\
\text { Commission }\end{array}$ & 35 & 5 & 60 \\
\hline Total & 350 & 45 & \\
\hline Total & $\mathbf{3 5 0}$ & $\mathbf{1 0 5}$ & 6 \\
\hline
\end{tabular}

\subsection{Research Instruments}

The primary data from government officials and the general public who were served by these Officials was collected through questionnaires and interview guide.

\subsubsection{Questionnaire}

Questionnaires were adopted in this study in order to source the primary data. Questionnaires have been adopted due to the following reasons; it gives a wide scope in that more respondents were reached at same time give adequate time for the respondent to the questionnaires, secondly it offers the sense of confidentiality to what the respondents give concerning the items in the questionnaires (as in an interview) (Mugenda \& Mugenda, 1999). The questionnaire was also aid in collected more research information and data from the sampled government officials. These questionnaires were divided into three main areas; the first section was the area that captures the demographic characteristics of the sampled research respondents. The rest of the sections were organized in a manner that covers the major research objectives.

\subsubsection{Interview guide}

This is a list of questions an interviewer aims to cover during an interview in course of his/her research work on a topic of interest. It is an effective tool for maintaining consistency during the interview so as to ensure quality results of the research.

\subsection{Reliability}

As indicated in the record the research instruments must be undertaken through reliability test in order to determine if they are reliable. An instrument must yield consistent result when adopted more than once in collection of two samples which are randomly drawn from the same population (Mugenda \& Mugenda, 1999). In order to determine the reliability the researcher conducted the pilot test to the instruments with use of different groups having the same characteristics like those targeted in the study. This pilot study aimed at determining whether the set research objectives were made or achieved and if there was any ambiguity in the process. It further gave the confirmation of whether the data acquired can meet or address the research objectives. Lastly reliability aided in indicating whether the given data type was meaningful after analysis in relation to the so called research objectives and research questions. The research population was encouraged in making the comments and suggestions which concerns the clarity of the question and relevancy of the same item in the instrument.

\subsubsection{Validity}

Validity on the other hand aided in deterring the research findings as what they are expected (Balta 2008). Validity is the capacity of the research instrument i.e. questionnaire to measure what was expected to be measured. Content validity in this study was tested by examining the pertinent literature, discussions with the experts in the questionnaire formulation stage so as to make sure there was enough and represented set of items. Feedback that was obtained from the pilot study of 10 government officials were used to revise the questionnaire and modify ambiguous items so as to merge the needs of the study before the actual process of data collection.

\subsection{Data Analysis Procedures}

After the process of administering and collection of the questionnaires, the information gathered was then examined through analysis and checked for the data completeness to suit the statistical analysis requirements. There after the information gathered was processed through a series of editing, coding and analysis using Microsoft excel sheet and SPSS. Data was edited to remove inconsistencies (Mugenda and Mugenda, 1999).

According to Mugenda and Mugenda (2003) it entails the description and application of the techniques intended for use in analyzing data. The study employed descriptive and inferential analysis

\subsection{Ethical Issues}

Research ethics tend to give the behaviors that give moral control of the choices relating to the researcher's deeds. As pointed out by Punch (2011), the experiential research takes most ethical issues which the researcher need to identify as well as show how they are dealt with. In a research, some of the ethical issues that should be considered include; participation voluntary, respondents respect, the anonymity and also confidentiality. For this study, the investigator sought authorization from the University and NACOSTI. 


\section{DATA ANALYSIS AND PRESENTATION}

\subsection{Introduction}

This chapter entails presentation and analysis of data from respondents. The results aims at answering the objectives of the study that include: to identify the gender gaps in the National gender Policy as a step towards achieving gender equality in Jubek state, determine the success of the national gender policy in gender mainstreaming in Jubek State and finally determine stakeholders' achievement in national gender policy in Jubek State

\subsection{Response Rate}

The researcher administered 45 questionnaires for government officials of Jubek State in the State Ministries of; Gender, Education, Health, Justice, Interior, Finance, Agriculture, Public Service and South Sudan Human Rights Commission. Out of which all the respondents returned their questionnaires, representing a return rate of $100 \%$. The respondents from the public also all returned their questionnaires representing a return rate of $100 \%$. Mugenda Mugenda (2003) pointed out that a return rate of $70 \%$ is considered appropriate. Therefore with a return rate of $100 \%$, is an excellent response.

\subsection{Demographic Factors}

The demographic factors of the respondents included the gender, age bracket, period worked for the organization and marital status.

From the table 4.1, out of the 45 government officials whose data was collected from, the majority were male accounting for $71.1 \%$ while $28.9 \%$ were female. Also in general public, out of 60 respondents $65 \%$ were male while only $35 \%$ were female. This shows the wide gender representation gap in the State Ministries of; Gender, Education, Health, Justice, Interior, Finance, Agriculture, Public Service and South Sudan Human Rights Commission. As indicated by the review by World Bank (2016) there are South Sudanese ladies who have accomplished a healthy degree of strengthening and specific abilities and capabilities needed to lead and definitively partake in dynamic at public level. Notwithstanding, the frameworks, institutional standards and disposition of certain men in certain organizations actually present snags for the advancement of these ladies to stand firm on higher situations and use their abilities and insight in offering types of assistance to the country

As indicated in the table above most of the government officials were in the age bracket of 26-35 representing 35.6\%. This was followed by the age bracket of 36-45 representing $33.3 \%$ while the minority age group accounted for $6.7 \%$ were in the age bracket of 56-65. The same scenario was in the general public where $45 \%$ were in age bracket of 26-35 followed by the age bracket of 36-35 representing $26.7 \%$ and the less represented age group is 56-65 representing 5.0\%. This implies that the majority of working population is middle aged while the young and the older age group not well represented in the working space. The discoveries resound with that of Sudan, (2021) who show that youthful South Sudanese experience issues getting work, yet that the nature of the positions that they in the long run do get is low

As from the table above, numerous participants (42\%) indicated that they have worked in Jubek State State Ministries for a period of 3-5 years. This was followed by those who have worked for in the stage ministries for 6-10 years. This implies that numerous participants understand the issues of gender having worked in the state ministries for a long period of time. Also from the table, most of the respondents both from the government officials and the general public were married. $84.4 \%$ of the government officials were married while $73.3 \%$ of the respondents were also married.

Table 4.1 Demographic factors

\begin{tabular}{|c|c|c|}
\hline Demographic factors & $\begin{array}{l}\text { Frequency } \\
\text { (F) }\end{array}$ & $\begin{array}{c}\text { Percentage } \\
(\%)\end{array}$ \\
\hline \multicolumn{3}{|l|}{ Government Officials } \\
\hline \multicolumn{3}{|l|}{ Gender } \\
\hline Male & 32 & 71.1 \\
\hline Female & 13 & 28.9 \\
\hline \multicolumn{3}{|l|}{ Age bracket } \\
\hline $\begin{array}{c}18-25 \\
26-35\end{array}$ & $\begin{array}{c}4 \\
16\end{array}$ & $\begin{array}{c}8.9 \\
35.6\end{array}$ \\
\hline $36-45$ & 15 & 33.3 \\
\hline $46-55$ & 7 & 15.6 \\
\hline $56-65$ & 3 & 6.7 \\
\hline \multicolumn{3}{|c|}{ Period worked for the organization } \\
\hline Less than two years & 9 & 20.0 \\
\hline 3-5 years & 19 & 42.2 \\
\hline $6-10$ years & 15 & 33.3 \\
\hline $11-15$ years & 1 & 2.2 \\
\hline Over 15 years & 1 & 2.2 \\
\hline \multicolumn{3}{|l|}{ Marital Status } \\
\hline Married & 38 & 84.4 \\
\hline Single & 4 & 8.9 \\
\hline Divorced & 3 & 6.7 \\
\hline \multicolumn{3}{|l|}{ Sub-total } \\
\hline \multicolumn{3}{|l|}{ GENERAL PUBLIC } \\
\hline \multicolumn{3}{|l|}{ Gender } \\
\hline Male & 39 & 65 \\
\hline Female & 21 & 35 \\
\hline \multicolumn{3}{|l|}{ Age bracket } \\
\hline $\begin{array}{c}18-25 \\
26-35\end{array}$ & $\begin{array}{c}6 \\
27 \\
\end{array}$ & $\begin{array}{l}10.0 \\
45.0 \\
\end{array}$ \\
\hline $36-45$ & 16 & 26.7 \\
\hline $46-55$ & 8 & 13.3 \\
\hline $56-65$ & 3 & 5.0 \\
\hline
\end{tabular}




\begin{tabular}{|c|c|c|}
\hline Marital Status & & \\
\hline Married & 44 & 73.3 \\
\hline Single & 11 & 18.3 \\
\hline Divorced & 5 & 8.3 \\
\hline Total & & \\
\hline
\end{tabular}

Source: Researcher, 2021

\subsection{The gender gaps in the National gender Policy}

The study aimed at assessing the gender mainstreaming adopted as a policy in the state ministries. This incorporates familiarity with the presence of the South Sudan National Gender Policy (SSNGP); Government increment of monetary distribution for mediations to expand degrees of consistency for young ladies and young men in schools; fuse of sex balance and basic freedoms in proficiency projects to sharpen networks on the adverse consequences of sex based separation; government refinement of networks on the privileges and advantages of training for all kids; consolidation of basic liberties, sex equity, regenerative wellbeing and freedoms and fundamental abilities as required courses in the public instruction educational plan at all levels; government supporting effort for young lady kid instruction.

\subsubsection{The Government officials response on gender gaps in the National gender Policy}

From the table $4.2,35.6 \%$ of the participants designated that they are not aware of the presence of the South Sudan National Gender Policy (SSNGP) while the majority 64.4\% indicated that they were aware. This implies that the majority of the government officials in state ministries are well informed on South Sudan National Gender Policy (SSNGP). The results further indicate that $64.4 \%$ of the participants designated that there is no easy availability of copies of the SSNGP in the public.

The majority of the respondent indicated that SSNGP has been high priority in organizational decision-making with $55.6 \%$ indicated yes while $44.4 \%$ dissented. The study sought to understand whether the government support campaign for girl-child education. However from the results majority of the respondents $(55.6 \%)$ agreed with the statement while $37.8 \%$ indicated that the government doesn't campaign for girl-child education. On whether the there is existence of a gender unit in the organization frequently visited for services, $44.4 \%$ of the respondents denied while the majority $55.6 \%$ agreed.

The study further sought to understand government sensitization of communities, on the rights and benefits of education for all children. However from the findings it is evident that government does sensitize the communities, on the rights and benefits of education for all children. This can be seen from the $53.3 \%$ of the respondents who agreed while only $46.7 \%$ of the government officials dissented. As indicated by The Sudd Institute in its uncommon report wrote by Mayai and Hammond, the Impact of Violence on Education in South Sudan (2014) affirmed, "Since the CPA time instruction has been of little significance to the public authority of South Sudan, with the current disobedience progressively fueling this issue. South Sudan's financial plan portion [for] the instruction area has been extraordinarily low, remaining somewhere in the range of 5 and 7 percent [of complete government expenditure] each year, and addresses the most minimal on the planet (Good Planet Foundation, 2013)

The following inquiry the review tried to comprehend in case there is accentuation of sexual orientation balance across the association and guaranteed during enrolment. From the results presented in the table 4.2 above, the majority $64.4 \%$ indicated that there is no emphasis of gender balance across the organization and ensured during recruitment while $35.5 \%$ agreed with the statement. On the next question of whether gender responsive training and retraining programs have been established, $68.8 \%$ dissented while 31.1 agreed. This implies that there is little effort on establishment of gender responsive training and retraining programs. The following inquiry tried to see if staff gets backing to fabricate abilities/mindfulness for sexual orientation mainstreaming where there are deficiencies. From the outcomes the greater part $(53.3 \%)$ didn't know while $24.4 \%$ showed that No and $22.2 \%$ concurred. This demonstrates that there is little work to help staff to assemble abilities/mindfulness for sex mainstreaming where there are deficiencies.

The other inquiry tried to comprehend whether enlistment/direction of new Staff remember a preparation for 'sexual orientation mainstreaming. From the table outcomes introduced, $35.6 \%$ contradicted while $31.1 \%$ concurred. This suggests that there is lacking direction of new staff on 'sex mainstreaming. The concentrate likewise looked to comprehend in case there are sufficient assets assigned for sex mainstreaming. From the review results introduced, there is no sufficient asset situated for sexual orientation mainstreaming. This can be seen by a greater part of respondents (64.4\%) who disagreed while just $35.6 \%$ demonstrated the presence of sufficient assets.

From the table above, on whether or not states support crusade for young lady youngster schooling, $60.0 \%$ concurred while $40.0 \%$ clashed. Likewise $68.9 \%$ of the respondents contradicted that there is consolidation of common freedoms, sex balance, regenerative wellbeing and privileges and fundamental abilities as required courses in the public instruction educational program at all levels while just 31.1\% concurred. The concentrate likewise additionally tried to comprehend from the other inquiry whether government increments monetary designation for mediations to expand consistency standards for young ladies and young men in schools. From table 4.2 above, $35.6 \%$ of the respondents contradicted while the larger part $64.4 \%$ concurred.

On the other inquiry of whether government sharpen networks on the freedoms and advantages of training for all youngsters, $33.3 \%$ of the respondents contradicted while the greater part $66.7 \%$ concurred. This infers that there is government work to 
sharpen networks on the freedoms and advantages of schooling for all youngsters. On the last inquiry the review looked for comprehends whether fuse of sexual orientation equity and common liberties in proficiency projects to sharpen networks on the adverse consequences of sex based segregation. Anyway from the discoveries introduced, $31.1 \%$ of the respondent disagreed while $40.0 \%$ concurred. This connotes that without a doubt joining of sexual orientation balance and common liberties in proficiency projects to sharpen networks on the adverse consequences of sex based segregation.

Table 4.2 the Government officials response on gender gaps in the National gender Policy

\begin{tabular}{|c|c|c|c|c|c|c|}
\hline \multirow{2}{*}{$\begin{array}{l}\text { Gender mainstreaming } \\
\text { adopted as a policy in the } \\
\text { state ministries sector }\end{array}$} & \multicolumn{2}{|l|}{ No } & \multicolumn{2}{|c|}{ Sort of } & \multicolumn{2}{|c|}{ Yes } \\
\hline & $\mathbf{F}$ & $\%$ & $\mathbf{F}$ & $\%$ & $\mathbf{F}$ & $\%$ \\
\hline $\begin{array}{l}\text { Awareness of the existence of } \\
\text { the South Sudan National } \\
\text { Gender Policy (SSNGP) }\end{array}$ & 16 & 35.6 & - & - & 29 & 64.4 \\
\hline $\begin{array}{l}\text { Easy availability of copies of } \\
\text { the SSNGP in the public }\end{array}$ & 29 & 64.4 & 3 & 6.7 & 13 & 28.9 \\
\hline $\begin{array}{l}\text { SSNGP given high priority in } \\
\text { organizational decision-making }\end{array}$ & 20 & 44.4 & - & - & 25 & 55.6 \\
\hline $\begin{array}{l}\text { The government } \\
\text { campaign for } \\
\text { education }\end{array}$ & 17 & 37.8 & 3 & 6.7 & 25 & 55.6 \\
\hline $\begin{array}{l}\text { Existence of a gender unit in } \\
\text { the organization frequently } \\
\text { visited for services }\end{array}$ & 20 & 44.4 & - & - & 25 & 55.6 \\
\hline $\begin{array}{l}\text { Government sensitization of } \\
\text { communities, on the rights and } \\
\text { benefits of education for all } \\
\text { children }\end{array}$ & 21 & 46.7 & - & - & 24 & 53.3 \\
\hline $\begin{array}{l}\text { Expectations of the role of each } \\
\text { staff clear in terms of 'gender } \\
\text { mainstreaming }\end{array}$ & 26 & 57.8 & & & 19 & 42.2 \\
\hline $\begin{array}{l}\text { Emphasis of gender balance } \\
\text { across the organization and } \\
\text { ensured during recruitment }\end{array}$ & 29 & 64.4 & & & 16 & 35.5 \\
\hline $\begin{array}{l}\text { Gender responsive training and } \\
\text { retraining programs established }\end{array}$ & 31 & 68.9 & & & 14 & 31.1 \\
\hline $\begin{array}{l}\text { Staff receive support to build } \\
\text { skills / awareness for gender } \\
\text { mainstreaming where there are } \\
\text { deficits }\end{array}$ & 11 & 24.4 & 24 & 53.3 & 10 & 22.2 \\
\hline $\begin{array}{l}\text { Induction/orientation of new } \\
\text { Staff include a briefing on } \\
\text { 'gender mainstreaming' }\end{array}$ & 16 & 35.6 & 15 & 33.3 & 14 & 31.1 \\
\hline $\begin{array}{l}\text { Adequate resources allocated } \\
\text { for gender mainstreaming }\end{array}$ & 29 & 64.4 & - & - & 16 & 35.6 \\
\hline $\begin{array}{llr}\begin{array}{l}\text { Government } \\
\text { campaign } \\
\text { education }\end{array} \text { for } & & \text { supporting } \\
\text { girl-child }\end{array}$ & 27 & 60.0 & - & - & 18 & 40.0 \\
\hline $\begin{array}{l}\text { Incorporation of human rights, } \\
\text { gender equality, reproductive } \\
\text { health and rights and life skills } \\
\text { as mandatory courses in the } \\
\text { national education curriculum } \\
\text { at all levels }\end{array}$ & 14 & 31.1 & - & - & 31 & 68.9 \\
\hline $\begin{array}{llr}\text { Government } & \text { increase } & \text { of } \\
\text { financial allocation for } & \text { for } \\
\text { interventions to increase } \\
\text { retention rates for girls and } \\
\text { boys in schools }\end{array}$ & 29 & 64.4 & & & 16 & 35.6 \\
\hline $\begin{array}{l}\text { Government sensitization of } \\
\text { communities on the rights and }\end{array}$ & 30 & 66.7 & - & - & 15 & 33.3 \\
\hline
\end{tabular}

\begin{tabular}{|c|c|c|c|c|c|c|}
\hline $\begin{array}{l}\text { benefits of education for all } \\
\text { children }\end{array}$ & & & & & & \\
\hline $\begin{array}{l}\text { Incorporation of gender } \\
\text { equality and human rights in } \\
\text { literacy programs to sensitize } \\
\text { communities on the negative } \\
\text { effects of gender-based } \\
\text { discrimination }\end{array}$ & 14 & 31.1 & 13 & 28.9 & 18 & 40.0 \\
\hline
\end{tabular}

\subsubsection{General public response on gender gaps in the National} gender Policy

From the table 4.3 , the greater part $76.7 \%$ of the respondents demonstrated that they don't know about the presence of the South Sudan National Gender Policy (SSNGP) while the larger part $23.3 \%$ showed that they knew. This infers that most of the overall population doesn't know about the South Sudan National Gender Policy (SSNGP). The outcomes further demonstrate that greater part $55.0 \%$ of the respondents showed that there is no simple accessibility of duplicates of the SSNGP in general society.

Most of the respondent showed that SSNGP has not been high need in authoritative dynamic with $30.0 \%$ demonstrated yes while $70.0 \%$ disagreed. The concentrate likewise looked to comprehend whether the public authority support crusade for young lady kid training. Anyway from the outcomes greater part of the respondents $(71.1 \%)$ contradicted the assertion while $28.3 \%$ demonstrated that the public authority lobbies for young lady kid instruction. On whether the there is presence of a sexual orientation unit in the association much of the time visited for administrations, $56.7 \%$ of the respondents denied while the greater part $15.0 \%$ concurred.

The examinations further needed to comprehend government sharpening of networks, on the privileges and advantages of training for all kids. Anyway from the discoveries it is clear that administration doesn't sharpen the networks, on the privileges and advantages of instruction for all youngsters. This can be seen from the 80.0 of the respondents who differ while just $20.0 \%$ of the public authority authorities concurred. The following inquiry the review tried to comprehend in case there is accentuation of sex balance across the association and guaranteed during enlistment. From the outcomes introduced in the table 4.2 over, the larger part $73.3 \%$ showed that there is no accentuation of sex balance across the association and guaranteed during enlistment while $26.7 \%$ concurred with the assertion.

On the following inquiry of whether sexual orientation responsive preparing and retraining programs have been set up $80.0 \%$ disagreed while $20.0 \%$ concurred. This suggests that there is little exertion on foundation of sex responsive preparing and retraining programs. The concentrate likewise looked to comprehend in case there are sufficient assets dispensed for sexual orientation mainstreaming. From the review results introduced, there are no sufficient assets situated for sexual orientation mainstreaming. This can be seen by a greater part of respondents (56.7\%) who contradicted while just $43.3 \%$ showed the presence of satisfactory assets. 
From the table above, on whether or not government upholds crusade for young lady kid instruction, $73.3 \%$ differ while $26.7 \%$ concurred. Likewise $71.1 \%$ of the respondents contradicted that there is joining of common liberties, sexual orientation balance, regenerative wellbeing and freedoms and fundamental abilities as required courses in the public instruction educational plan at all levels while just $28.3 \%$ concurred. The concentrate likewise additionally tried to comprehend from the other inquiry whether government increments monetary assignment for intercessions to build consistency standards for young ladies and young men in schools. From table 4.2, 55.0\% of the respondents contradicted while the greater part $18.3 \%$ concurred.

On whether or not government sharpen networks on the freedoms and advantages of instruction for all kids, $81.7 \%$ of the respondents contradicted while the $18.3 \%$ concurred. This suggests that there is little exertion by the public authority to sharpen networks on the privileges and advantages of training for all youngsters. In conclusion, the last inquiry the review looked for comprehends whether fuse of sex equity and common freedoms in proficiency projects to sharpen networks on the adverse consequences of sex based segregation. Anyway from the discoveries introduced, $56.7 \%$ of the respondent contradicted while $43.3 \%$ concurred. This implies that there is no joining of sex equity and common liberties in proficiency projects to sharpen networks on the adverse consequences of sexual orientation based segregation

From the public authority authorities talked with, a large portion of them comprehend the South Sudan National Gender Policy. The authorities further showed that their separate associations have sex mainstreaming methodology in any case; it has not been completely executed. The authorities further respect ladies' part in initiative and dynamic positions doesn't achieves positive outcomes and changes. They likewise affirmed that sex balance isn't mainstreamed in harmony dealings at all levels there is on the grounds that little trust in ladies initiative. The authorities further showed that there is without a doubt no sex balance accentuated across the association and guaranteed during enlistment. This in light of the fact that the majority of individuals who select are male and subsequently they tend blessing individual men and furthermore view ladies as substandard.

The authorities further uncovered that staff doesn't get sufficient help to fabricate abilities/mindfulness for sex mainstreaming where there are shortfalls. Additionally the acceptance/direction of new Staff doesn't to a great extent remember a preparation for 'sex mainstreaming and hence sexual orientation examination not required piece of association's work. The public authority engaged with backing for the nullification of standard laws that limit ladies' admittance to land and useful assets through sanctioning of laws and enactment. Notwithstanding, the significant test is the execution
Table 4.3 General public response on gender gaps in the National gender Policy

\begin{tabular}{|c|c|c|c|c|c|c|}
\hline \multirow{2}{*}{$\begin{array}{l}\text { Gender mainstreaming } \\
\text { adopted as a policy in the } \\
\text { education sector }\end{array}$} & \multicolumn{2}{|c|}{ No } & \multicolumn{2}{|c|}{ Sort of } & \multicolumn{2}{|c|}{ Yes } \\
\hline & $\mathbf{F}$ & $\%$ & $\mathbf{F}$ & $\%$ & $\mathbf{F}$ & $\%$ \\
\hline \begin{tabular}{lll}
\multicolumn{3}{l}{ Awareness of the existence } \\
of the & South & Sudan \\
National Gender & Policy \\
(SSNGP) & & \\
\end{tabular} & 46 & 76.7 & - & - & 14 & 23.3 \\
\hline $\begin{array}{l}\text { Easy availability of copies } \\
\text { of the SSNGP in the public }\end{array}$ & 33 & 55.0 & & & 27 & 45.0 \\
\hline $\begin{array}{l}\text { SSNGP given high priority } \\
\text { in organizational decision- } \\
\text { making }\end{array}$ & 42 & 70.0 & - & - & 18 & 30.0 \\
\hline $\begin{array}{l}\text { The government supporting } \\
\text { campaign for girl-child } \\
\text { education }\end{array}$ & 43 & 71.1 & & & 17 & 28.3 \\
\hline $\begin{array}{l}\text { Existence of a gender unit } \\
\text { in the organization } \\
\text { frequently visited for } \\
\text { services }\end{array}$ & 34 & 56.7 & 17 & 28.3 & 9 & 15.0 \\
\hline $\begin{array}{l}\text { Government sensitization } \\
\text { of communities, on the } \\
\text { rights and benefits of } \\
\text { education for all children }\end{array}$ & 48 & 80.0 & - & - & 12 & 20.0 \\
\hline $\begin{array}{l}\text { Expectations of the role of } \\
\text { each staff clear in terms of } \\
\text { 'gender mainstreaming }\end{array}$ & 33 & 55.0 & & & 27 & 45.0 \\
\hline $\begin{array}{l}\text { Emphasis of gender balance } \\
\text { across the organization and } \\
\text { ensured during recruitment }\end{array}$ & 44 & 73.3 & & & 16 & 26.7 \\
\hline $\begin{array}{l}\text { Gender responsive training } \\
\text { and retraining programs } \\
\text { established }\end{array}$ & 48 & 80.0 & & & 12 & 20.0 \\
\hline $\begin{array}{l}\text { Staff receive support to } \\
\text { build skills / awareness for } \\
\text { gender mainstreaming } \\
\text { where there are deficits }\end{array}$ & & & & & & \\
\hline $\begin{array}{l}\text { Induction/orientation of } \\
\text { new Staff include a briefing } \\
\text { on 'gender mainstreaming' }\end{array}$ & & & & & & \\
\hline $\begin{array}{lr}\begin{array}{l}\text { Adequate } \\
\text { allocated for }\end{array} & \text { gesources } \\
\text { mainstreaming } & \\
\end{array}$ & 34 & 56.7 & - & - & 26 & 43.3 \\
\hline 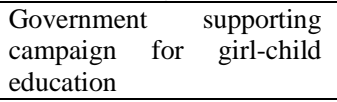 & 44 & 73.3 & - & - & 16 & 26.7 \\
\hline $\begin{array}{l}\text { Incorporation of human } \\
\text { rights, gender equality, } \\
\text { reproductive health and } \\
\text { rights and life skills as } \\
\text { mandatory courses in the } \\
\text { national education } \\
\text { curriculum at all levels }\end{array}$ & 43 & 71.1 & - & - & 17 & 28.3 \\
\hline $\begin{array}{l}\text { Government increase of } \\
\text { financial allocation for } \\
\text { interventions to increase } \\
\text { retention rates for girls and } \\
\text { boys in schools }\end{array}$ & 33 & 55.0 & 16 & 26.7 & 11 & 18.3 \\
\hline $\begin{array}{l}\text { Government sensitization } \\
\text { of communities on the } \\
\text { rights and benefits of } \\
\text { education for all children }\end{array}$ & 48 & 81.7 & - & - & 11 & 18.3 \\
\hline $\begin{array}{l}\text { Incorporation of gender } \\
\text { equality and human rights } \\
\text { in literacy programs to } \\
\text { sensitize communities on } \\
\text { the negative effects of } \\
\text { gender-based } \\
\text { discrimination }\end{array}$ & 34 & 56.7 & & & 26 & 43.3 \\
\hline
\end{tabular}




\subsection{Success of the national gender policy in gender mainstreaming}

This goal pointed toward discovering the Success of the public sexual orientation strategy in sex mainstreaming. From table $4.4,60.0 \%$ of the respondents contradicted the view that audit of all wellbeing related enactment, approaches and projects to incorporate and standard sex equity while $40.0 \%$ concurred. This connotes that there is little exertion on survey of all wellbeing related enactment, strategies and projects to incorporate and standard sexual orientation equity.

The following inquiry tried to comprehend in case there are systems set up to dispose of imbalance among people in admittance to wellbeing administrations, their reasonableness and usage. From the discoveries, the larger part 37.8\% demonstrates that there are no such system while just $20.0 \%$ concurred that there are such instrument.

The concentrate likewise looked to see whether there are distribution of sufficient and supported asset and monetary portion to key maternal and kid wellbeing regions like inoculation, against malarial mediations, water and sterilization, birthing specialists and mother and youngster laborers. Anyway from the review discoveries, $64.4 \%$ said no while just $35.6 \%$ said OK. This infers that there is little exertion by the public authority distribution of sufficient and supported asset and monetary assignment to key maternal and youngster wellbeing regions.

The following inquiry the review looked to see whether there is accessibility of arrangements with the expectation of complimentary risk natal and pre-natal consideration, medicinally helped conveyance and refinement lobbies for pregnant and lactating ladies to use the offices. From the review discoveries, the larger part $44.4 \%$ of the respondents said no while just $35.6 \%$ concurred.

The concentrate additionally looked to comprehend in case there is presence of purposeful work to give equivalent admittance to data on sexual and regenerative wellbeing specifically on anti-conception medication and solid kid dispersing. As demonstrated in the table over, the larger part $64.4 \%$ said no while $35.6 \%$. This infers that there is no conscious work to give equivalent admittance to data on sexual and regenerative wellbeing specifically on conception prevention and solid kid dividing.

The other inquiry additionally tried to comprehend in case there is an uncommon consideration paid to juvenile young men and young ladies in the association's projects. From the table, greater part $68.9 \%$ differ while $31.1 \%$ concurred. The discoveries imply that there is no unique consideration paid to young adult young men and young ladies in the association's projects.

On the following inquiry the review tried to see whether there is a unique consideration paid to pregnant ladies, to lessen mother-to-youngster transmission of HIV. From the review brings about the table, the greater part $68.9 \%$ of the respondents had a view that there is no consideration paid to pregnant ladies, to lessen mother-to-kid transmission of HIV while just $31.1 \%$ concurred with the assertion.

On whether there is sex mainstreaming all through the food creation area, including esteem expansion, bundling and advertising. Most of respondents $46.7 \%$ said there is no sex mainstreaming all through the food creation area, including esteem expansion, bundling and advertising while just $37.8 \%$ concurred.

The concentrate additionally tried to see if there are fitting monetary assets and specialized administrations set up and accommodated country ladies in the horticultural and food creation areas, like preparing in worked on cultivating rehearses, food stockpiling and protection, esteem option and advertising. Notwithstanding, from the outcomes introduced in table 4.4 over, the greater part $64.4 \%$ dismissed this similarity while just $35.6 \%$ concurred

Most of respondents $66.7 \%$ showed that there has not been sufficient distribution of assets for limited scope agribusiness and better admittance to water, energy, transport and markets while $33.3 \%$ concurred. This infers that limited scale farming don't get satisfactory assets for better admittance to water, energy, transport and markets.

The concentrate likewise looked to see whether sexual orientation examination and GRB is mainstreamed in all full scale financial approaches and related enactment to guarantee ladies and men advantage fairly from the economy. The outcomes introduced in table show that the greater part $64.4 \%$ differ while $35.6 \%$ concurred.

On the last inquiry, the review looked to comprehend in case there is presence of progressive enhancement of the country's income base past the petrol area to areas where most individuals, particularly ladies, infer their vocation like agribusiness. The outcomes demonstrate that most of the respondents $55.6 \%$ contradicted while just $44.4 \%$ concurred with the assertion.

Table 4.4 Government Officials Gender equality mainstreamed in health programs and allocation of funds for services

\begin{tabular}{|l|l|l|l|l|l|l|}
\hline \multirow{2}{*}{$\begin{array}{l}\text { Gender equality mainstreamed in health programs and } \\
\text { allocation of funds for services }\end{array}$} & \multicolumn{2}{l|}{ No } & \multicolumn{2}{l|}{ Sort of } & \multicolumn{2}{l|}{ Yes } \\
\cline { 2 - 8 } & F & $\%$ & F & $\%$ & F & $\%$ \\
\hline $\begin{array}{l}\text { Review of all health-related legislation, policies and programs } \\
\text { to integrate and mainstream gender equality }\end{array}$ & 27 & 60.0 & & & 18 & 40.0 \\
\hline $\begin{array}{l}\text { Mechanisms in place to elim inate inequality between men and } \\
\text { women in access to health services, their affordability and } \\
\text { utilization }\end{array}$ & 28 & 62.2 & & & 17 & 37.8 \\
\hline $\begin{array}{l}\text { Allocation of adequate and sustained resource and budgetary } \\
\text { allocation to key maternal and child health areas such as } \\
\text { immunization, anti-malarial interventions, water and } \\
\text { sanitation, midwives and mother and child workers }\end{array}$ & 29 & 64.4 & & & 16 & 35.6 \\
\hline $\begin{array}{l}\text { Availability of provisions for frec ante-natal and pre-natal } \\
\text { care, medically assisted delivery and sensitization campaigns } \\
\text { for pregnant and lactating women to utilize the facilitics }\end{array}$ & 20 & 44.4 & 9 & 20.0 & 16 & 35.6 \\
\hline $\begin{array}{l}\text { Presence of deliberate effort to provide equal access to } \\
\text { information on sexual and reproductive health in particular on } \\
\text { birth control and healthy child spacing }\end{array}$ & 29 & 64.4 & & & 16 & 35.6 \\
\hline $\begin{array}{l}\text { special attention paid to adolescent boys and girls in the } \\
\text { organization's programs }\end{array}$ & 31 & 68.9 & & & 14 & 31.1 \\
\hline
\end{tabular}




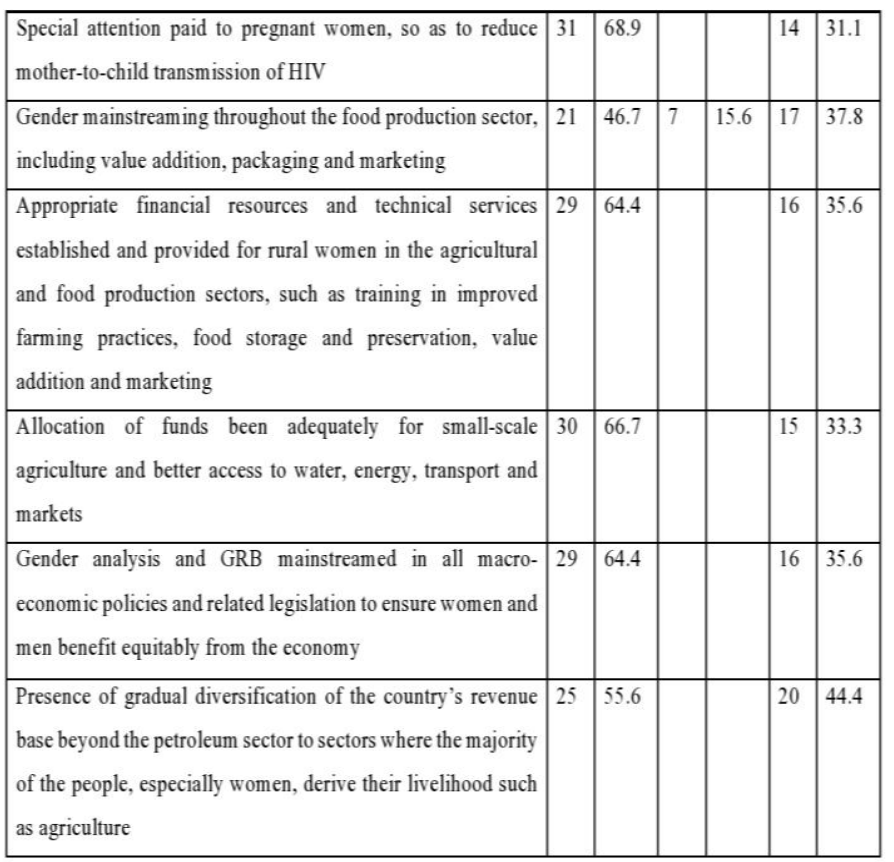

4.5.1 General public on Gender equality mainstreamed in health programs and allocation of funds for services

From table $4.5,75.0 \%$ of the respondents contradicted the view that audit of all wellbeing related enactment, arrangements and projects to coordinate and standard sex uniformity while $25.0 \%$ concurred. This implies that there is little exertion on survey of all wellbeing related enactment, strategies and projects to incorporate and standard sex correspondence. The following inquiry looked to comprehend in case there are components set up to kill imbalance among people in admittance to wellbeing administrations, their reasonableness and usage. From the discoveries, the larger part $80.0 \%$ demonstrates that there is no such system while just $20.0 \%$ concurred that there is such component.

The concentrate likewise tried to see whether there are allotment of satisfactory and supported asset and monetary designation to key maternal and youngster wellbeing regions like vaccination, hostile to malarial intercessions, water and sterilization, birthing specialists and mother and kid laborers. Anyway from the review discoveries, $56.7 \%$ said no while just $20.0 \%$ said OK. This infers that there is little exertion by the public authority portion of sufficient and supported asset and monetary distribution to key maternal and kid wellbeing regions.

The following inquiry the review tried to see whether there is accessibility of arrangements with the expectation of complimentary risk natal and pre-natal consideration, therapeutically helped conveyance and refinement lobbies for pregnant and lactating ladies to use the offices. From the review discoveries, the larger part $73.3 \%$ of the respondents said no while just $26.7 \%$ concurred. The concentrate additionally looked to comprehend if presence of purposeful work to give equivalent admittance to data on sexual and conceptive wellbeing specifically on contraception and solid kid separating. As shown in the table over, the greater part $56.7 \%$ said no while $43.3 \%$. This suggests that there is no conscious work to give equivalent admittance to data on sexual and regenerative wellbeing specifically on contraception and sound youngster dividing.

The other inquiry likewise tried to comprehend in case there is an exceptional consideration paid to juvenile young men and young ladies in the association's projects. From the table, greater part $75.0 \%$ differ while $25.0 \%$ concurred. The discoveries connote that there is no uncommon consideration paid to juvenile young men and young ladies in the association's projects. On the following inquiry the review tried to see whether there is an uncommon consideration paid to pregnant ladies, in order to diminish mother-to-kid transmission of HIV. From the review brings about the table, the greater part $71.1 \%$ of the respondents had a view that there is no consideration paid to pregnant ladies, in order to decrease mother-to-youngster transmission of HIV while just $28.3 \%$ concurred with the assertion.

On whether there is sex mainstreaming all through the food creation area, including esteem expansion, bundling and advertising. Most of respondents $65.0 \%$ said there is no sex mainstreaming all through the food creation area, including esteem expansion, bundling and advertising while just $25.0 \%$ concurred. The concentrate additionally looked to see if there are proper monetary assets and specialized administrations set up and accommodated provincial ladies in the agrarian and food creation areas, like preparing in worked on cultivating rehearses, food stockpiling and conservation, esteem option and advertising. Be that as it may, from the outcomes introduced in table 4.5 over, the larger part $66.7 \%$ dismissed this similarity while just $31.7 \%$ concurred

Most of respondents $65.0 \%$ demonstrated that there have not been sufficient allotments of assets for limited scope farming and better admittance to water, energy, transport and markets while $35.0 \%$ concurred. This infers that limited scale agribusiness don't get satisfactory assets for better admittance to water, energy, transport and markets. The concentrate likewise looked to see whether sexual orientation examination and GRB is mainstreamed in all full scale monetary arrangements and related enactment to guarantee ladies and men advantage evenhandedly from the economy. The outcomes introduced in table demonstrate that the larger part $71.7 \%$ differ while $35.0 \%$ concurred.

On the last inquiry, the review tried to comprehend in case there is presence of slow expansion of the country's income base past the petrol area to areas where most individuals, particularly ladies, infer their work like farming. The outcomes show that most of the respondents $71.7 \%$ disagreed while just $16.7 \%$ concurred with the assertion. Additionally from the authorities met there has been insignificant finished Projects identified with SSNGP Implementation and furthermore on-going Projects Related to SSNGP Implementation. Additionally as indicated by the authorities Family Code been authorized to direct issues like separation 
and legacy be that as it may, there has not been sufficient work to see its full execution

Table 4.5 General public on Gender equality mainstreamed in health programs and allocation of funds for services

\begin{tabular}{|l|l|l|l|l|l|l|}
\hline \multirow{2}{*}{$\begin{array}{l}\text { Gender equality mainstreamed in health programs and } \\
\text { allocation of funds for services }\end{array}$} & \multicolumn{2}{l}{ No } & \multicolumn{3}{l|}{ Sort of } & \multicolumn{2}{l|}{ Yes } \\
\cline { 2 - 8 } & F & $\%$ & F & $\%$ & F & $\%$ \\
\hline $\begin{array}{l}\text { Review of all health-related legislation, policies and programs } \\
\text { to integrate and mainstream gender equality }\end{array}$ & 45 & 75.0 & & & 15 & 25.0 \\
\hline $\begin{array}{l}\text { Mechanisms in place to eliminate inequality between men and } \\
\text { women in access to health services, their affordability and } \\
\text { utilization }\end{array}$ & 48 & 80.0 & & & 12 & 20.0 \\
\hline $\begin{array}{l}\text { Allocation of adequate and sustained resource and budgetary } \\
\text { allocation to key maternal and child health areas such as }\end{array}$ & 34 & 56.7 & 14 & 23.3 & 12 & 20.0 \\
\hline
\end{tabular}

\begin{tabular}{|c|c|c|c|c|c|c|}
\hline $\begin{array}{l}\text { immunization, anti-malarial interventions, water and } \\
\text { sanitation, midwives and mother and child workers }\end{array}$ & & & & & & \\
\hline $\begin{array}{l}\text { Availability of provisions for free ante-natal and pre-natal } \\
\text { care, medically assisted delivery and sensitization campaigns } \\
\text { for pregnant and lactating women to utilize the facilities }\end{array}$ & 44 & 73.3 & & & 16 & 26.7 \\
\hline $\begin{array}{l}\text { Presence of deliberate effort to provide equal access to } \\
\text { information on sexual and reproductive health in particular on } \\
\text { birth control and healthy child spacing }\end{array}$ & 34 & 56.7 & & & 26 & 43.3 \\
\hline $\begin{array}{l}\text { special attention paid to adolescent boys and girls in the } \\
\text { organization's programs }\end{array}$ & 45 & 75.0 & & & 15 & 25.0 \\
\hline $\begin{array}{l}\text { Special attention paid to pregnant women, so as to reduce } \\
\text { mother-to-child transmission of HIV }\end{array}$ & 43 & 71.1 & & & 17 & 28.3 \\
\hline $\begin{array}{l}\text { Gender mainstreaming throughout the food production sector, } \\
\text { including value addition, packaging and marketing }\end{array}$ & 39 & 65.0 & 6 & 10.0 & 16 & 25.0 \\
\hline $\begin{array}{l}\text { Appropriate financial resources and technical services } \\
\text { established and provided for rural women in the agricultural } \\
\text { and food production sectors, such as training in improved } \\
\text { farming practices, food storage and preservation, value } \\
\text { addition and marketing }\end{array}$ & 40 & 66.7 & 1 & 1.7 & 19 & 31.7 \\
\hline $\begin{array}{l}\text { Allocation of funds been adequately for small-scale } \\
\text { agriculture and better access to water, energy, transport and } \\
\text { markets }\end{array}$ & 39 & 65.0 & & & 21 & 35.0 \\
\hline $\begin{array}{l}\text { Gender analysis and GRB mainstreamed in all macro- } \\
\text { economic policies and related legislation to ensure women and } \\
\text { men benefit equitably from the economy }\end{array}$ & 43 & 71.7 & & & 21 & 35.0 \\
\hline $\begin{array}{l}\text { Presence of gradual diversification of the country's revenue } \\
\text { base beyond the petroleum sector to sectors where the } \\
\text { majority of the people, especially women, derive their } \\
\text { livelihood such as agriculture }\end{array}$ & 43 & 71.7 & 7 & 11.7 & 10 & 16.7 \\
\hline
\end{tabular}

\subsection{Stakeholders' achievement in national gender policy}

This true targets discovering the partners accomplishment in public sexual orientation strategy which incorporate ladies' business associations and cooperatives shaped
From table 4.6, the review tried to discover the association support for the arrangement of ladies' business and business visionaries' associations, including cooperatives, and giving them institutional and human limit building backing like utilitarian proficiency and preparing in business and monetary administration. From the outcomes $28.9 \%$ of the respondents differ while the larger part $71.1 \%$ disagreed. The following inquiry tried to comprehend the accessibility of plans to build up a Women's Bank and fortify other monetary administrations, for example, VSLAs with the end goal of killing sex disparities in admittance to capital, credit and other monetary administrations. The outcomes demonstrated that $28.9 \%$ said no while $28.9 \%$ concurred.

Table 4.6 Government Officials response on women's business organizations and cooperatives formed

\begin{tabular}{|c|c|c|c|c|c|c|}
\hline \multirow{2}{*}{$\begin{array}{lr}\text { Women's } & \text { business } \\
\text { organizations } & \text { and } \\
\text { cooperatives formed } & \end{array}$} & \multicolumn{2}{|c|}{ No } & \multicolumn{2}{|c|}{ Sort of } & \multicolumn{2}{|c|}{ Yes } \\
\hline & $\mathbf{F}$ & $\%$ & $\mathbf{F}$ & $\%$ & $\mathbf{F}$ & $\%$ \\
\hline $\begin{array}{l}\text { The organization support for } \\
\text { the formation of women's } \\
\text { business and entrepreneurs' } \\
\text { organizations, including } \\
\text { cooperatives, and providing } \\
\text { them with institutional and } \\
\text { human capacity building } \\
\text { support such as functional } \\
\text { literacy and training in } \\
\text { business and financial } \\
\text { management }\end{array}$ & 13 & 28.9 & & & 32 & 71.1 \\
\hline $\begin{array}{l}\text { Availability of plans to } \\
\text { establish a Women's Bank and } \\
\text { strengthen other financial } \\
\text { services such as VSLAs with a } \\
\text { view to eliminating gender } \\
\text { inequalities in access to } \\
\text { capital, credit and other } \\
\text { financial services }\end{array}$ & 13 & 28.9 & 19 & 42.2 & 13 & 28.9 \\
\hline
\end{tabular}

4.6.1 General public response on women's business organizations and cooperatives formed

From the table 4.7, the review looked to discover the association support for the development of ladies' business and business people's associations, including cooperatives, and giving them institutional and human limit building backing like practical education and preparing in business and monetary administration. The outcomes as introduced in table above demonstrated that most of the respondents $68.0 \%$ said no while just $20.0 \%$ of the respondents concurred. The last inquiry looked for comprehend the accessibility of plans to set up a Women's Bank and reinforce other monetary administrations, for example, VSLAs with the end goal of taking out sex disparities in admittance to capital, credit and other monetary administrations. From the review results, $55.0 \%$ while the rest $45.0 \%$ contradicted. 
Table 4.7 General public response on women's business organizations and cooperatives formed

\begin{tabular}{|c|c|c|c|c|c|c|}
\hline \multirow[b]{2}{*}{$\begin{array}{l}\text { Women's business organizations } \\
\text { and cooperatives formed }\end{array}$} & \multicolumn{2}{|l|}{ No } & \multicolumn{2}{|c|}{ Sort of } & \multicolumn{2}{|c|}{ Yes } \\
\hline & $\mathbf{F}$ & $\%$ & $\mathbf{F}$ & $\%$ & $\mathbf{F}$ & $\%$ \\
\hline $\begin{array}{l}\text { The organization support for the } \\
\text { formation of women's business and } \\
\text { entrepreneurs' organizations, } \\
\text { including cooperatives, and } \\
\text { providing them with institutional } \\
\text { and human capacity building support } \\
\text { such as functional literacy and } \\
\text { training in business and financial } \\
\text { management }\end{array}$ & 41 & 68.3 & 7 & 11.7 & 12 & 20.0 \\
\hline $\begin{array}{l}\text { Availability of plans to establish a } \\
\text { Women's Bank and strengthen other } \\
\text { financial services such as VSLAs } \\
\text { with a view to eliminating gender } \\
\text { inequalities in access to capital, } \\
\text { credit and other financial services }\end{array}$ & 33 & 55.0 & & & 27 & 45.0 \\
\hline
\end{tabular}

\section{SUMMARY, CONCLUSION AND RECOMMENDATIONS}

\subsection{Introduction}

This section entails summary of the study findings, conclusion and recommendation for further studies.

\subsection{Summary of the Study Findings}

\subsubsection{Demographic factors}

Larger part of the respondents were male contrasted with female who were the minority. As caught in the outcomes, the greater part of both government authorities and the overall population were in the age section of 26-35. Notwithstanding, the less addressed gathering was in the age section of 56-65. Most government authorities in various state services at Jubek state have for a time of 3-5 years. This was trailed by the people who have worked for in the stage services for 6-10 years. Likewise from the outcomes, the majority of the respondents both from the public authorities and the overall population were hitched.

\subsubsection{Gender gaps in the National gender Policy}

The greater part of the public authority authorities showed that they don't know about the presence of the South Sudan National Gender Policy (SSNGP) contrasted with the overall population who greater part demonstrated that they don't know about the presence of South Sudan National Gender Policy (SSNGP). Government authorities showed that SSNGP has been high need in hierarchical dynamic. This was opposite with the overall population who felt that SSNGP has not been high need in hierarchical dynamic.

The public authority authorities from various state services concurred that the public authority support crusade for young lady kid schooling contrasted with the assessment of the overall population who showed that there is no administration support for young lady youngster training. The examinations further need to comprehend government refinement of networks, on the privileges and advantages of training for all youngsters. Anyway from the discoveries it is obvious that administration doesn't sharpen the networks, on the freedoms and advantages of training for all youngsters.

The outcomes additionally showed that administration doesn't sharpen networks on the freedoms and advantages of schooling for all youngsters. This was by both the public authority authorities met and the overall population. Likewise there is no fuse of sexual orientation equity and basic liberties in proficiency projects to sharpen networks on the adverse consequences of sex based separation

\subsubsection{Success of the national gender policy in gender mainstreaming}

The public authority authorities demonstrated that there is no accentuation of gender balance across the association and guarantee during enrollment. Additionally gender responsive preparing and retraining programs have not been set up. This was by both the overall population and the public authorities. The outcomes likewise showed that there are no satisfactory assets dispensed for gender orientation mainstreaming. The outcomes likewise showed that the public authority doesn't increment monetary distribution for intercessions to build consistency standards for young ladies and young men in schools

Larger part of the respondents disagreed the view that survey of all wellbeing related enactment, strategies and projects to coordinate and standard sexual orientation balance. Larger part of the respondents additionally demonstrated that there are no such systems. Larger part of the respondents additionally showed that there are no portion of satisfactory and supported asset and monetary distribution to key maternal and kid wellbeing regions like vaccination, hostile to malarial intercessions, water and disinfection, birthing specialists and mother and youngster laborers. Furthermore, most of the respondents likewise showed that there is no accessibility of arrangements with the expectation of complimentary risk natal and pre-natal consideration, medicinally helped conveyance and sharpening lobbies for pregnant and lactating ladies to use the offices.

The review results additionally demonstrated that there is no presence of conscious work to give equivalent admittance to data on sexual and conceptive wellbeing specifically on contraception and solid kid dividing. The outcomes introduced in part four above additionally demonstrated that greater part of the respondents from both the public authority authorities working in different state services and the public authority state services said there is no uncommon consideration paid to juvenile young men and young ladies in the association's projects

The outcomes further demonstrated that there is no a unique consideration paid to pregnant ladies, to lessen mother-toyoungster transmission of HIV. The outcomes further demonstrated that larger part of the respondents from both the public authority state services of Jubek and the overall population showed that there is no gender responsive strategies all through the food creation area, including esteem 
expansion, bundling and promoting. Most of the respondents likewise showed that there are no proper monetary assets and specialized administrations set up and accommodated rustic ladies in the horticultural and food creation areas, like preparing in worked on cultivating rehearses, food stockpiling and protection, esteem expansion and advertising.

Larger part of respondents likewise showed that there has not been satisfactory portion of assets for limited scope horticulture and better admittance to water, energy, transport and markets. As per most of the respondents, sexual orientation examination and GRB is no mainstreamed in all full scale financial approaches and related enactment to guarantee ladies and men advantage fairly from the economy. Additionally there is no presence of steady enhancement of the country's income base past the oil area to areas where most individuals, particularly ladies, infer their business like agribusiness

\subsubsection{Stakeholders' achievement in national gender policy}

Larger part of the respondents from both the public authority authorities working in different state services in Jubek state demonstrated that administration divisions don't uphold the arrangement of ladies' business and business visionaries' associations, including cooperatives, and furnishing them with institutional and human limit building backing like practical education and preparing in business and monetary administration. Likewise greater part of the respondents demonstrated that there is no accessibility of plans to build up a Women's Bank and reinforce other monetary administrations, for example, VSLAs with the end goal of disposing of sexual orientation disparities in admittance to capital, credit and other monetary administrations.

\subsection{Conclusion}

The review uncovered that there is wide whole overall portrayal in work in government state services of Jubek. The male sex rules the business contrasted with their female partners. The concentrate additionally uncovered that regardless of the presence of South Sudan National Gender Policy (SSNGP), its execution is as yet and not satisfactory since the overall population isn't even mindful of its reality and there is no attention to general society on the significance of the South Sudan National Gender Policy (SSNGP).

The concentrate additionally presumed that there is no accentuation public sex strategy in sexual orientation mainstreaming. Gender orientation responsive preparing and retraining programs have not been set up. There are likewise no sufficient assets assigned for gender mainstreaming. The public authority doesn't increment monetary designation for mediations to build standards for dependability for young ladies and young men in schools. Hence the public sexual orientation strategy in gender mainstreaming has not delivered any achievement.

The review discoveries further uncovered that partners in public gender strategy have not accomplished a ton.
Government divisions don't uphold the arrangement of ladies' business and business visionaries' associations, including cooperatives, and furnishing them with institutional and human limit building backing like useful education and preparing in business and monetary administration. Likewise there is no accessibility of plans to build up a Women's Bank and fortify other monetary administrations, for example, VSLAs with the end goal of killing gender imbalances in admittance to capital, credit and other monetary administrations.

\subsection{Recommendations}

i. There is need for the public authority state services to set up stricter measures to guarantee there is sex value in work in both private and public assistance

ii. There is likewise need for the public authority partners to make attention to the general population on the significance and execution of Sudan National Gender Policy (SSNGP)

There is likewise need for the public authority to allot sufficient assets for sexual orientation mainstreaming.

iii. The public authority likewise need to increment monetary portion for mediations to build standards for dependability for young ladies and young men in schools. Hence the public sexual orientation strategy in gender mainstreaming has not created any achievement

iv. The public authority need to help arrangement of ladies' business and business people's associations, including cooperatives, and giving them institutional and human limit building backing like useful proficiency and preparing in business and monetary administration.

\subsection{Recommendation for further study}

i). Other studies need to focus on factors contributing to poor implementation of Sudan National Gender Policy (SSNGP)

ii). The future studies also need to focus on attitude and perception of gender equality in south Sudan and also gender Sudan National Gender Policy (SSNGP)

\section{REFERENCES}

[1] Abusharaf, R. M. (2009). Transforming displaced women in Sudan: politics and the body in a squatter settlement. University of Chicago Press.

[2] Ali, N. M. (2011). Gender and state building in South Sudan. US Institute of Peace.

[3] Arabi, A. (2011). In power without power': Women in politics and leadership positions in South Sudan. Hope, Pain \& Patience: The Lives of Women in South Sudan, 193-213.

[4] Arostegui, J. (2013). Gender, conflict, and peace-building: How conflict can catalyse positive change for women. Gender \& Development, 21(3), 533-549.

[5] Balta, M. E. (2008). The impact of business environment and boards of directors on strategic decision-making: A case study of Greek listed companies (Doctoral dissertation, Brunel University Brunel Business School PhD Theses) 
[6] Barriteau, V. E. (2000). Feminist theory and development: implications for policy, research and action. Theoretical perspectives on gender and development, 161- 178

[7] Benería, L., Berik, G., \& Floro, M. (2015). Gender, development and globalization: economics as if all people mattered. Routledge.

[8] Carey, H. F. (2001). 'Women and peace and security': The politics of implementing gender sensitivity norms in peacekeeping. International Peacekeeping, 8(2), 49-68.

[9] De Waal, A., \& Mohammed, A. (2014). Breakdown in South Sudan. Foreign Affairs.

[10] Ebila, F. (2003). Uganda: Mainstreaming Gender into Policy: Examining Uganda's Gender Water Strategy.

[11] Edward, J. (2011). Women and political participation in South Sudan. Sudan Tribune.

[12] Edward, J. K. (2014). A strategy for achieving gender equality in South Sudan. Weekly Review. Juba, South Sudan: The Sudd Institute.

[13] Edward, J. K. (2014). A strategy for achieving gender equality in South Sudan. Weekly Review. Juba, South Sudan: The Sudd Institute.

[14] Fordham, M. (2003). Gender, disaster and development. Natural disasters and development in a globalizing world. Routledge, London, 57-74.
[15] Majekodunmi, A. A. (2006). 10. NIGERIA: Using Gender Mainstreaming Processes to Help Protect Drinking Water Sources of the Obudu Plateau Communities in Northern Cross River State. Gender, Water and Sanitation, 62.

[16] Mannan, H., McVeigh, J., Amin, M., MacLachlan, M., Swartz, L., Munthali, A., \& Van Rooy, G. (2012). Core concepts of human rights and inclusion of vulnerable groups in the disability and rehabilitation policies of Malawi, Namibia, Sudan, and South Africa. Journal of Disability Policy Studies, 23(2), 67-81.

[17] Mjøen, A. O. (2015). Women's participation in statebuilding with a focus on South Sudan, Rwanda and Nepal (Master's thesis, Norwegian University of Life Sciences, Ås).

[18] Mugenda, O. \& Mugenda, G. (2003). Research Methods: Quantitative and Qualitative Approaches. Nairobi: African Centre for Technology Studies.

[19] National Gender Policy, (2013). Ministry Of Gender, Child and Social Welfare. The Republic Of South Sudan, 1-66

[20] Okumu J. (2012) Gender mainstreaming and promotion of gender equality: A case study of the Swedish Cooperative Centre, Viagroforestry project, Kisumu-Kenya. Examensarbete i Hållbar Utveckling 90

[21] Sudan, F. (2021). Technological Disruptions, Youth Unemployment and Vocational Education Challenges in South Asia: A Short Report. Global Economics Science, 80-97. doi: $10.37256 /$ ges. 222021769 